\title{
Instability and impending instability of the thoracolumbar spine in patients with spinal metastases: a systematic review
}

\author{
MICHAEL H. WEBER ${ }^{1}$, SHANE BURCH ${ }^{2}$, JENNY BUCKLEY ${ }^{2}$, MEIC H. SCHMIDT ${ }^{3}$, \\ MICHAEL G. FEHLINGS ${ }^{4}$, FRANK D. VRIONIS ${ }^{5}$ and CHARLES G. FISHER ${ }^{1}$ \\ ${ }^{1}$ Division of Spine, Department of Orthopaedics, University of British Columbia, Blusson Spinal Cord Centre, \\ 6th floor, 818 West 10th Avenue, Vancouver, BC V5Z 1M9, Canada; ${ }^{2}$ Department of Orthopaedics, \\ University of California, San Francisco, 400 Parnassus Ave., ACC, Third Floor, San Francisco, CA 94143; \\ ${ }^{3}$ Huntsman Cancer Institute and Department of Neurosurgery, Clinical Neurosciences Center, \\ University of Utah, 175 North Medical Drive, Salt Lake City, UT 84132-0001, USA; ${ }^{4}$ Department of Surgery, \\ University of Toronto, Toronto Western Hospital Spinal Program, 4th Floor, Rm 4WW449, 399 Bathurst St., \\ Toronto, ON M5T 2S8, Canada; ${ }^{5} \mathrm{H}$. Lee Moffitt Cancer Center and Research Institute and Departments of \\ Neurosurgery and Interdisciplinary Oncology, University of South Florida College of Medicine, \\ 12902 Magnolia Drive, Tampa, FL 33612, USA
}

Received June 10, 2010; Accepted August 2, 2010

DOI: 10.3892/ijo_00000818

\begin{abstract}
Metastatic disease commonly occurs in the spine and incidence is likely to increase secondary to improved survival rates in many cancer patients. Despite published research on instability in patients with metastatic disease of the thoracolumbar spine, controversy exists regarding risk factors for instability and indications for surgical stabilization. The objective of this systematic review was to determine what defines instability and impending instability in patients with metastatic disease of the thoracic and lumbar spine. We systematically reviewed the medical literature in order to identify all the relevant studies concerning patients with metastatic involvement of T1-L5, in the domains of biomechanics, epidemiology, clinical issues, and radiographic parameters. Two independent observers performed study selection, methodological quality assessment, and data extraction in a blinded and objective manner for all the identified studies. We were then able to define the criteria to identify instability of the spine with metastases. A literature search and review identified 14 relevant, good quality studies for inclusion. The predictors of instability included increased tumor size, a larger cross-sectional area of bone defect, increased force of spinal loading, decreased bone density, posterior location of the tumor within the vertebrae, destruction of the costovertebral joint, pedicle destruction in the thoracolumbar
\end{abstract}

Correspondence to: Dr Charles G. Fisher, Vancouver General Hospital, Blusson Spinal Cord Centre, 6th floor, 818 West 10th Avenue, Vancouver, BC V5Z 1M9, Canada E-mail: charles.fisher@vch.ca

Key words: instability, spinal metasases, systematic review spine, increased axial rigidity, and sagittal spinal deformity. Definitive conclusions cannot be reached due to lack of evidence. However, variables such as tumor size, magnitude of spinal loading, bone density, tumor location within the vertebrae and spine, and tumor type are risk factors for instability in spinal metastases. Improved clinical research methodology for this patient population is required.

\section{Contents \\ 1. Introduction \\ 2. Methods \\ 3. Summary results \\ 4. Conclusions}

\section{Introduction}

In the United States, $\sim 1.5$ million cancer cases are diagnosed annually (1). The most common metastases arise from breast cancer and the majority, $\sim 30 \%$, are located in the spine (2). Currently, $>10 \%$ of cancer patients develop symptoms secondary to spinal metastases (3). This rate will likely increase as the prevalence of spinal metastases increases with the improved survival in cancer patients (1).

Surgical decompression and stabilization in patients with spinal metastatic disease is now feasible and is supported by strong evidence, due to advances in biomaterials, imaging and surgical techniques (4-6). However, in patients who do not present with neurological deficits, indications for spinal stabilization are poorly defined and objective guidelines are required. In order to identify candidates with spinal instability secondary to metastases, a detailed understanding of the anatomical, clinical, radiological and pathological variables 
that influence stability is required. This information will help patients and the allied healthcare team make medical and surgical decisions using evidence based on recommendations related to instability.

The objective of this study was to apply the methodology of systematic reviews $(7,8)$ to the problem of what defines instability or impending instability in patients with metastatic disease of the thoracolumbar spine. The search was restricted to studies on the thoracolumber spine in order to eliminate the variability in the literature. However, it was not restricted as to the type of metastasis, thereby increasing the potential number of studies considered.

\section{Methods}

This systematic review addresses the question: 'What defines instability and impending instability in patients with metastatic disease of the thoracic and lumbar spine?'

Inclusion/exclusion criteria. Inclusion criteria were defined a priori into 3 broad categories: Study population, independent variables, and the outcome measured. To this effect, studies included in this systematic review met the following criteria: i) They described patients with metastatic involvement of T1-L5 vertebra ii) they commented on the biomechanics, epidemiology, clinical issues, or radiographic parameters associated with metastatic spine involvement, and iii) they defined instability of the spine.

Literature search to identify primary studies. A comprehensive medical literature search was conducted in order to identify all the potential studies. An electronic database search of Medline and Embase was performed using medical subject headings (MeSH) and text word searching (Table I). A search of the electronic database of CINAHL was also carried out using the same search strategy. The Database of Abstracts of Reviews of Effects and the Cochrane Database of Systematic Reviews were also searched using text words. Reference lists from relevant articles were individually searched for additional articles. Expert opinion was also sought.

Study selection. Two independent reviewers (M.H.W. and C.G.F.) with advanced epidemiology training and content expertise used a standardized study selection worksheet to evaluate the eligibility of each article. The reviewers were blinded to the authors, institutions and journals of publication. Based on abstract review only, articles were excluded if both the reviewers independently believed that the inclusion criteria were not met. All the remaining studies were assessed using the complete reports. Any disagreements were resolved by discussion.

Assessment of methodological quality. Studies which met the inclusion criteria were subject to methodological quality assessment by the same 2 blinded, independent reviewers $(9,10)$. A standardized quality assessment tool was developed (Table II). Based on expert opinion, an a priori decision was made, that a study with a score $>50 \%$ was assigned a 'very good' grade, otherwise, a 'good' grade was assigned. Reviewer disagreements were resolved through discussion.
Data extraction. Using a modification of the critical review form for quantitative studies developed by Law et al (11), the 2 reviewers undertook data extraction independently. All available data, including methods and results were extracted, and agreement between the 2 reviewers was verified.

Statistical analysis. Although data was extracted from all included studies, reported results were based on studies judged to contain 'very good' methodology, to ensure valid conclusions. Due to the absence of homogeneous randomized control trials (RCTs), a meta-analysis was not performed and a qualitative synthesis of the published literature was planned.

\section{Summary results}

Locating primary studies and study selection. A literature search for primary studies (performed in August 2007) identified 39 potential studies. After a review of the abstracts, the selection process eliminated 25 studies, primarily because the studies addressed treatment and failed to meet our inclusion criteria for defining instability. An additional 7 studies were excluded after review of their methodology and results sections. The reviewers unanimously agreed during the selection phase based on the abstracts and on a review of the entire study ( $\kappa$ of 1$)$. After a review of the reference lists of the selected studies and correspondence with experts in the field, an additional 7 studies met the inclusion criteria. In total, this selection process found 14 relevant studies for inclusion in this systematic review (Table III).

Methodological quality assessment. Based on the methodological quality assessment (Table II), all 14 studies were categorized as 'very good' quality. However, common deficiencies among studies still existed and these included the lack of a specific research question, no description of the sample population, no explanation of eligible patients (and/or specimens) who did not participate, and the lack of blinded or objective outcome assessments.

\section{Methodological composites of the selected studies}

Computer modeling (finite element analysis). All five studies by Whyne and colleagues in the review examined the effects of applied loads on a finite-element model of the spine with and without metastatic defects. In the first study, Whyne et al, 2003 (12) developed and validated a threedimensional poroelastic spinal model with metastatic involvement in order to evaluate the effects of lytic lesions, spinal loading and motion segment status on the risk of initiating burst fracture and canal compromise. The model results suggested that tumor size contributed mostly towards the risk of initiating burst fracture, followed by the applied load magnitude and bone density. In the study by Roth et al (13), the ability of a three-dimensional poroelastic finite element model for the metastatically involved spine to predict vertebral stability and a clinical threshold for burst fracture risk, was examined. The authors also generated a method for obtaining the data required to determine the burst fracture risk. In the retrospective analysis of this study, the vertebral bulge model, displacement in the horizontal plane, and using only the load-bearing capacity (constant pressure load), 
Table I. Medline search for relevant studies in which the impact on bone metastases on the stability of the thoracolumbar spine was examined.

\begin{tabular}{|c|c|c|}
\hline 1. & 'Lumbar Vertebrae' (MeSH), 'Thoracic Vertebrae' ( MeSH), 'thoracolumbar vertebrae', or 'thoracolumbar spine' & 32175 \\
\hline 2. & 'Biomechanics' (MeSH), biomechanics (TIAB), or columns (TIAB) & 518790 \\
\hline 3. & 'Epidemiology’ (MeSH), or ‘epidemiology’ (subheading) & 986839 \\
\hline 5. & 'Magnetic Resonance Imaging’ (MeSH) & 168541 \\
\hline 6. & ‘Neoplasm Metastasis’ (MeSH), metastases (TIAB), or metastasis (TIAB) & 202954 \\
\hline 7. & Instability (TIAB), stability (TIAB), unstable (TIAB), collapse (TIAB), or failure (TIAB) & 521246 \\
\hline 9. & Nos. 8 and 1 & 76 \\
\hline 10. & Nos. 9 and $2,3,4$, or 5 & 39 \\
\hline
\end{tabular}

Table II. The methodological quality assessment tool used to rate studies derived from the literature search. ${ }^{\mathrm{a}}$

\section{Is there a clear statement of purpose?}

Was the study design RCT or a prospective cohort?

Was the assessor blinded?

Is the outcome defined and method of diagnosis stated?

Did the authors account for every patient (or sample) that was eligible but was not entered? ${ }^{\mathrm{b}}$

Is the method clearly defined and replicable? Were all patients (or samples) accounted for $\left(<25 \%\right.$ lost to FU) ? ${ }^{\text {b }}$

Were outcome measures relevant to the primary question?

Was statistical significance considered?

Were tests applied appropriately?

Was sample size calculated prior to study? ${ }^{\text {b }}$

Were the results/conclusions clinically significant?

aIf the answer to each question was affirmative, then a check was made; ${ }^{\mathrm{b}}$ question not applicable in retrospective studies; FU, follow-up.

showed $100 \%$ predictive power for burst fractures in metastatically involved vertebrae. Vertebral axial displacement showed a very high predictive ability, although the volumetric estimate of the tumor size suggested only a limited predictive ability. Neither study yielded a clear threshold between the burst fracture and intact groups. In the study by Tschirhart et al (14), again using poroelastic parametric finite element modeling, the effects of tumor location and shape on vertebral body stability and burst fracture risk in the metastatic spine, were quantified. Posterior localization of the tumor caused the greatest increase in vertebral bulge (retropulsion). Tumor shape was also an important predictor of stability. Tumors with a medial to lateral dimension demonstrated an increased vertebral bulge, whereas, tumors which spanned the greatest distance in the axial direction experienced more axial displacement. The results suggested that tumor volume alone does not entirely account for the geometric parameters affecting vertebral stability. In 2006, Tschirhart et al (15) evaluated the effects of multiple loading conditions on a metastatically-involved thoracic spinal motion segment. The results demonstrated that axial loading is the predominant load type, leading to the increased potential of burst fracture initiation, and rotational loading led to only a moderate increase in risk. The ribcage reduced burst fracture risk by $27 \%$. Finally, Tschirhart et al (16) examined the effects of thoracic vertebral level/geometry and metastatic compromise to the cortical shell on initiation of burst fracture risk in metastatically involved vertebrae. Upper thoracic vertebrae with metastatic involvement were found to be at increased risk of burst fracture compared to lower thoracic vertebral levels. Increased kyphotic angles and the ribcage decreased the risk of pathologic burst fracture initiation. Vertebrae with transcortical lesions were up to $30 \%$ less likely to have a burst fracture.

Animal models. The single cadaveric animal study by Ebihara et al (17), examined the effects of a simulated tumor size within the vertebral body and other spinal components on the probability of mechanical failures of the thoracic spine. This was a non-randomized prospective trial with a total of 99 fresh thoracic specimens (T7-T9, n= 49; T10-T12, $\mathrm{n}=50$ ) from 50 male sheep. The results showed that an increased simulated tumor size within the vertebral body proportionally decreased the failure load, and that the destruction of the costovertebral joint caused a greater risk for impending vertebral collapse.

Human cadaver models. Hipp et al (18), investigated whether, depending on the primary tumor type, density changes resulted in significant changes in mechanical properties. The strength of lytic specimens was less than normal $(p=0.057)$, while the strength of blastic specimens was not $(\mathrm{p}>0.1)$. Elasticity was less for both the blastic and lytic samples $(p<0.025)$. Apparent density explained both the variations in strength and elasticity $(\mathrm{p}<0.001)$.

Dimar et al (19) performed a cohort study to establish a reliable model for vertebral fracture. Thoracic vertebrae were physiologically loaded through adjacent discs in order to test vertebrae with defects involving cortical and cancellous bone and determine whether a geometric defect threshold exists. No threshold defect size was noted beyond which failure consistently occurred. Linear correlation analyses showed that the best parameter for predicting vertebral strength was the product of bone mineral density (BMD) and the remaining intact vertebral body cross-sectional area. This vertebral strength index correlated linearly with the strength of intact and compromised $\mathrm{T} 7$ vertebrae $\left(\mathrm{r}^{2}=0.52\right)$. 
Table III. Characteristics of the reviewed studies.

\begin{tabular}{|c|c|c|c|c|c|c|}
\hline Study & Origin of study & Design & $\begin{array}{l}\text { No. of participants } \\
\text { at final follow-up }\end{array}$ & Interventions & $\begin{array}{c}\text { Acceptable outcome } \\
\text { measures }\end{array}$ & Conclusions \\
\hline $\begin{array}{l}\text { Whyne et al } \\
\text { (12) }\end{array}$ & $\begin{array}{l}\text { Orthopaedic } \\
\text { Bioengineering } \\
\text { Laboratory } \\
\text { Department of } \\
\text { Orthopaedic Surgery, } \\
\text { University of California } \\
\text { San Francisco, CA, USA. }\end{array}$ & $\begin{array}{l}\text { Non- } \\
\text { randomized } \\
\text { prospective } \\
\text { study }\end{array}$ & $\begin{array}{l}12 \text { Fresh-frozen } \\
\text { cadaver spinal } \\
\text { motion segments } \\
\text { (T12 to L2) }\end{array}$ & $\begin{array}{l}\text { Lytic lesions, spinal } \\
\text { loading (magnitude } \\
\text { and loading rate) } \\
\text { and motion segment } \\
\text { (tumor size, disc quality } \\
\text { and vertebral quality) }\end{array}$ & $\begin{array}{l}\text { Vertebral bulge, } \\
\text { canal narrowing } \\
\text { and posterior wall } \\
\text { tensile hoop strain }\end{array}$ & $\begin{array}{l}\text { Burst fractures in } \\
\text { metastatically affected } \\
\text { vertebrae are initiated } \\
\text { by tumor size, } \\
\text { magnitude of spinal } \\
\text { loading, and bone } \\
\text { density }\end{array}$ \\
\hline $\begin{array}{l}\text { Roth et al } \\
\text { (13) }\end{array}$ & $\begin{array}{l}\text { Orthopaedic } \\
\text { Biomechanics } \\
\text { Laboratory, Sunnybrook } \\
\text { and Women's College } \\
\text { Health Sciences Centre, } \\
\text { Toronto, ON, Canada. }\end{array}$ & $\begin{array}{l}\text { Retrospective } \\
\text { study }\end{array}$ & 72 Patients & $\begin{array}{l}\text { Lytic vertebral body } \\
\text { fracture } \\
\text { (wedge vs. burst) }\end{array}$ & $\begin{array}{l}\text { Vertebral body volume, } \\
\text { minimum vertebral } \\
\text { cross-sectional area, } \\
\text { tumor volume, BMD, } \\
\text { and pressure load } \\
\text { applied }\end{array}$ & $\begin{array}{l}\text { Load-bearing capacity } \\
\text { (constant pressure } \\
\text { load) showed } \\
\text { excellent }(100 \%) \\
\text { predictive power } \\
\text { for burst fractures }\end{array}$ \\
\hline $\begin{array}{l}\text { Tschirhart } \\
\text { et al (14) }\end{array}$ & $\begin{array}{l}\text { Orthopaedic } \\
\text { Biomechanics } \\
\text { Laboratory, Sunnybrook } \\
\text { and Women's College } \\
\text { Health Sciences Centre, } \\
\text { Toronto, ON, Canada. }\end{array}$ & $\begin{array}{l}\text { Non- } \\
\text { randomized } \\
\text { prospective } \\
\text { study }\end{array}$ & $\begin{array}{l}16 \text { Ellipsoidal } \\
\text { tumor scenarios }\end{array}$ & $\begin{array}{l}\text { Tumor location, } \\
\text { shape (smooth or } \\
\text { serrated) and volume }\end{array}$ & $\begin{array}{l}\text { Maximum vertebral } \\
\text { bulge and maximum } \\
\text { vertebral axial } \\
\text { displacement }\end{array}$ & $\begin{array}{l}\text { Burst fracture is } \\
\text { dependent on } \\
\text { metastatic tumor } \\
\text { location and shape }\end{array}$ \\
\hline $\begin{array}{l}\text { Ebihara } \\
\text { et al (17) }\end{array}$ & $\begin{array}{l}\text { Department of } \\
\text { Orthopaedic Surgery, } \\
\text { Hokkaido University } \\
\text { Graduate School of } \\
\text { Medicine, Sapporo, } \\
\text { Japan. }\end{array}$ & $\begin{array}{l}\text { Non- } \\
\text { randomized } \\
\text { prospective } \\
\text { study }\end{array}$ & $\begin{array}{l}99 \text { Fresh thoracic } \\
\text { sheep spine } \\
\text { specimens } \\
(\mathrm{T} 7-\mathrm{T} 9, \mathrm{n}=49 \\
\text { T10-T12, n=50) }\end{array}$ & $\begin{array}{l}\text { Vertebral body defects } \\
\text { with or without } \\
\text { additional destruction of } \\
\text { costovertebral joint, } \\
\text { pedicle, and facet joint } \\
\text { all subjected to static } \\
\text { flexion-compression load }\end{array}$ & Vertebral collapse & $\begin{array}{l}\text { i) Increased tumor size } \\
\text { proportionally } \\
\text { decreases the failure } \\
\text { load, ii) destruction of } \\
\text { the costovertebral } \\
\text { joint is a high risk } \\
\text { factor for vertebral } \\
\text { collapse }\end{array}$ \\
\hline $\begin{array}{l}\text { Tschirhart } \\
\text { et al (15) }\end{array}$ & $\begin{array}{l}\text { Orthopaedic } \\
\text { Biomechanics } \\
\text { Laboratory, Sunnybrook } \\
\text { and Women's College } \\
\text { Health Sciences Centre, } \\
\text { Toronto, ON, Canada. }\end{array}$ & $\begin{array}{l}\text { Non- } \\
\text { randomized } \\
\text { prospective } \\
\text { study }\end{array}$ & $\begin{array}{l}12 \text { Cadaveric } \\
\text { spines }\end{array}$ & $\begin{array}{l}\text { Combined load } \\
\text { types }\end{array}$ & $\begin{array}{l}\text { Vertebral bulge, } \\
\text { canal narrowing and } \\
\text { posterior wall tensile } \\
\text { hoop strain }\end{array}$ & $\begin{array}{l}\text { i) Axial loading is the } \\
\text { predominant load type } \\
\text { leading to increased } \\
\text { risk of burst fracture } \\
\text { initiation, ii) inclusion } \\
\text { of the ribcage reduces } \\
\text { the potential for } \\
\text { burst fracture by } 27 \%\end{array}$ \\
\hline $\begin{array}{l}\text { Tschirhart } \\
\text { et al (16) }\end{array}$ & $\begin{array}{l}\text { Orthopaedic } \\
\text { Biomechanics } \\
\text { Laboratory, Sunnybrook } \\
\text { and Women's College } \\
\text { Health Sciences Centre, } \\
\text { Toronto, ON, Canada. }\end{array}$ & $\begin{array}{l}\text { Non- } \\
\text { randomized } \\
\text { prospective } \\
\text { study }\end{array}$ & $\begin{array}{l}7 \text { Scenarios } \\
\text { ranging in } \\
\text { geometry from } \\
\mathrm{T} 2-\mathrm{T} 4 \text { to } \\
\mathrm{T} 10-\mathrm{T} 12\end{array}$ & $\begin{array}{l}\text { Axial load to } \\
\text { transcortical tumor } \\
\text { scenarios }\end{array}$ & $\begin{array}{l}\text { Canal narrowing, } \\
\text { vertebral body with } \\
\text { trabecular bone pore } \\
\text { pressure, vertebral } \\
\text { bulge and posterior } \\
\text { wall tensile } \\
\text { hoop strain }\end{array}$ & $\begin{array}{l}\text { i) Upper, compared to } \\
\text { lower, thoracic } \\
\text { vertebrae are at } \\
\text { increased risk of burst } \\
\text { frature, ii) Increased } \\
\text { kyphotic angles } \\
\text { exhibited decreased } \\
\text { risk of fracture } \\
\text { iii) Transcortical } \\
\text { lesions are } 30 \% \\
\text { less likely to lead } \\
\text { to fracture }\end{array}$ \\
\hline $\begin{array}{l}\text { Taneichi } \\
\text { et al (24) }\end{array}$ & $\begin{array}{l}\text { Department of } \\
\text { Orthopaedic Surgery, } \\
\text { Hokkaido University } \\
\text { Graduate School of } \\
\text { Medicine, Sapporo, } \\
\text { Japan. }\end{array}$ & $\begin{array}{l}\text { Non- } \\
\text { randomized } \\
\text { retrospective } \\
\text { study }\end{array}$ & $\begin{array}{l}100 \text { Thoracic } \\
\text { and lumbar } \\
\text { vertebrae with } \\
\text { metastatic } \\
\text { tumors occuring } \\
\text { in } 53 \text { patients }\end{array}$ & $\begin{array}{l}\text { Tumor size, and } \\
\text { distribution (body, } \\
\text { costovertebral joint, } \\
\text { and posterior elements) }\end{array}$ & $\begin{array}{l}\text { Vertebral body } \\
\text { collapse }\end{array}$ & $\begin{array}{l}\text { Collapse is related to: } \\
\text { i) Costovertebral joint } \\
\text { destruction, ii) tumor } \\
\text { size in the thoracic } \\
\text { region (T1-T10), } \\
\text { iii) tumor size, } \\
\text { iv) pedicle destruction } \\
\text { in the thoracolumbar } \\
\text { spine (T10-L5) }\end{array}$ \\
\hline
\end{tabular}


Table III. Continued.

\begin{tabular}{|c|c|c|c|c|c|c|}
\hline Study & Origin of study & Design & $\begin{array}{l}\text { No. of participants } \\
\text { at final follow-up }\end{array}$ & Interventions & $\begin{array}{c}\text { Acceptable outcome } \\
\text { measures }\end{array}$ & Conclusions \\
\hline $\begin{array}{l}\text { Hipp et al } \\
\text { (18) }\end{array}$ & $\begin{array}{l}\text { Department of } \\
\text { Orthopaedic Surgery, } \\
\text { Charles A. Dana } \\
\text { Research Institute, } \\
\text { Boston, MA, USA. }\end{array}$ & $\begin{array}{l}\text { Non- } \\
\text { randomized } \\
\text { prospective } \\
\text { study }\end{array}$ & $\begin{array}{l}2 \text { Cadaver } \\
\text { donors with } \\
\text { metastases of } \\
\text { the lumber and } \\
\text { thoracic } \\
\text { vertebrae }\end{array}$ & $\begin{array}{l}\text { Uniaxial } \\
\text { compression for } \\
\text { strain and stress }\end{array}$ & $\begin{array}{l}\text { Densities and elasiticity } \\
\text { of mineralized tissue }\end{array}$ & $\begin{array}{l}\text { Lesions with } \\
\text { decreased density } \\
\text { (lytic) have less } \\
\text { strength than those } \\
\text { with increased } \\
\text { density (blastic) }\end{array}$ \\
\hline $\begin{array}{l}\text { Dimar } \\
\text { et al (19) }\end{array}$ & $\begin{array}{l}\text { Department of } \\
\text { Orthopaedic Surgery, } \\
\text { University of } \\
\text { Louisville } \\
\text { School of Medicine, } \\
\text { KY, USA. }\end{array}$ & $\begin{array}{l}\text { Non- } \\
\text { randomized } \\
\text { prospective } \\
\text { study }\end{array}$ & $\begin{array}{l}18 \text { Cadaver } \\
\text { thoracic spines } \\
\text { (T3-T11) }\end{array}$ & $\begin{array}{l}\text { Vertebral defect } \\
\text { (anterior through to } \\
\text { posterior cortex) and } \\
\text { CT BMD of remaining } \\
\text { body }\end{array}$ & $\begin{array}{l}\text { Load threshold } \\
\text { to failure }\end{array}$ & $\begin{array}{l}\text { Strength index } \\
\text { (remaining intact } \\
\text { vertebral cross- } \\
\text { sectional area x BMD) } \\
\text { can predict strength }\end{array}$ \\
\hline $\begin{array}{l}\text { Windhagen } \\
\text { et al }(50)\end{array}$ & $\begin{array}{l}\text { Department of } \\
\text { Orthopedic Surgery, } \\
\text { Charles A Dana } \\
\text { Research Institute, } \\
\text { Boston, MA, USA. }\end{array}$ & $\begin{array}{l}\text { Non- } \\
\text { randomized } \\
\text { prospective } \\
\text { study }\end{array}$ & $\begin{array}{l}32 \text { Fresh } \\
\text { cadaver, } \\
\text { 3-vertebrae } \\
\text { thoracic } \\
\text { segments }\end{array}$ & $\begin{array}{l}\text { Vertebral defect } \\
\text { and CT determined } \\
\text { axial rigidity of } \\
\text { midvertebral } \\
\text { cross-section }\end{array}$ & $\begin{array}{l}\text { Tested to failure } \\
\text { with axial compression } \\
\text { and anterior flexion }\end{array}$ & $\begin{array}{l}\text { Axial rigidity, and not } \\
\text { defect size, is related } \\
\text { to failure load }\end{array}$ \\
\hline $\begin{array}{l}\text { Windhagen } \\
\text { et al (21) }\end{array}$ & $\begin{array}{l}\text { Department of } \\
\text { Orthopedic Surgery, } \\
\text { Charles A Dana } \\
\text { Research Institute, } \\
\text { Boston, MA, USA. }\end{array}$ & $\begin{array}{l}\text { Non- } \\
\text { randomized } \\
\text { prospective } \\
\text { study }\end{array}$ & $\begin{array}{l}30 \text { Cadaver } \\
\text { spines (15 T10- } \\
\text { T12 and } \\
15 \text { T4-T6) }\end{array}$ & $\begin{array}{l}\text { Vertebral defect } \\
\text { and CT determined } \\
\text { structural properties }\end{array}$ & $\begin{array}{l}\text { Failure load and } \\
\text { post-fracture stability }\end{array}$ & $\begin{array}{l}\text { Post-fracture stability } \\
\text { linearly correlates } \\
\text { with both failure load } \\
\text { and axial rigidity }\end{array}$ \\
\hline $\begin{array}{l}\text { Whealan } \\
\text { et al (22) }\end{array}$ & $\begin{array}{l}\text { Orthopedic } \\
\text { Biomechanics } \\
\text { Laboratory, } \\
\text { Beth Israel } \\
\text { Deaconess Medical } \\
\text { Center and Harvard } \\
\text { Medical School, } \\
\text { Boston, MA, USA. }\end{array}$ & $\begin{array}{l}\text { Non- } \\
\text { randomized } \\
\text { prospective } \\
\text { study }\end{array}$ & $\begin{array}{l}34 \text { Fresh-frozen } \\
\text { cadaver spines } \\
(18 ; \text { T7-T9 and } \\
\text { 16; L1-L3 } \\
\text { spinal units) }\end{array}$ & $\begin{array}{l}\text { Vertebral defect } \\
\text { in } 1 \text { of } 3 \text { locations and } \\
\text { CT and bone scan } \\
\text { determined axial and } \\
\text { bending rigidities }\end{array}$ & $\begin{array}{l}\text { Axial load and bending } \\
\text { moment at failure with } \\
\text { combined compression } \\
\text { and forward flexion } \\
\text { was determined }\end{array}$ & $\begin{array}{l}\text { i) Defect size is a } \\
\text { poor predictor of } \\
\text { failure, ii) Image- } \\
\text { derived measures of } \\
\text { structural rigidity } \\
\text { correlated moderately } \\
\text { well with measured } \\
\text { yield loads }\end{array}$ \\
\hline $\begin{array}{l}\text { McGowan } \\
\text { et al (23) }\end{array}$ & $\begin{array}{l}\text { Orthopedic } \\
\text { Biomechanics } \\
\text { Laboratory, } \\
\text { Beth Israel } \\
\text { Deaconess Medical } \\
\text { Center and Harvard } \\
\text { Medical School, } \\
\text { Boston, MA, USA. }\end{array}$ & $\begin{array}{l}\text { Non- } \\
\text { randomized } \\
\text { retrospective } \\
\text { study }\end{array}$ & $\begin{array}{l}10 \text { Fresh } \\
\text { cadaver thoracic } \\
\text { spines }\end{array}$ & $\begin{array}{l}\text { Vertebral defect } \\
\text { (cross-sectional } \\
\text { area of the defect } \\
\text { divided by the nominal } \\
\text { cross-sectional area } \\
\text { of the vertebral } \\
\text { body mid-plane) }\end{array}$ & $\begin{array}{l}\text { Tested to failure } \\
\text { using combined } \\
\text { axial-flexion loads }\end{array}$ & $\begin{array}{l}\text { Strength is } \\
\text { proportional to the } \\
\text { cross-sectional area of } \\
\text { bone defect within } \\
\text { the centrum of } \\
\text { thoracic vertebrae }\end{array}$ \\
\hline $\begin{array}{l}\text { Asdourian } \\
\text { et al }(25)\end{array}$ & $\begin{array}{l}\text { William H. M. Finney } \\
\text { Spine Center, Union } \\
\text { Memorial Hospital, } \\
\text { Baltimore, MD, USA. }\end{array}$ & $\begin{array}{l}\text { Observational } \\
\text { clinical study }\end{array}$ & $\begin{array}{l}31 \text { MRI studies } \\
\text { on } 33 \text { thoracic } \\
\text { vertebrae of } \\
27 \text { patients }\end{array}$ & MRI & $\begin{array}{l}\text { Vertebrae with breast } \\
\text { cancer metastases } \\
\text { were observed to } \\
\text { undergo progressive } \\
\text { collapse with either } \\
\text { serial X-rays or } \\
\text { repeat MRI }\end{array}$ & $\begin{array}{l}\text { A pattern of sagittal } \\
\text { spinal deformity exists } \\
\text { with metastatic } \\
\text { vertebral breast cancer }\end{array}$ \\
\hline
\end{tabular}

$\mathrm{CT}$, computed tomography; BMD, bone mineral density; MRI, magnetic resonance imaging.

Windhagen et al (20) performed a cadaver study to determine the relationship between vertebral failure load and CT measurements including defect size and bone density. Linear regressions between axial rigidity (strength in the longitudinal plane) and absolute failure load demonstrated a high positive correlation, and there was no correlation between defect size and failure load. Windhagen et al (21) also investigated whether the post-fracture stability of lumbar and thoracic vertebrae could be predicted from non-invasive, pre-fracture measurements of structural properties. The 
Table IV. Quality assessment of the factors predictive of instability in the metastatic spine.

\begin{tabular}{|c|c|c|c|}
\hline Variable & Risk & $\begin{array}{l}\text { Predictive } \\
\text { value }\end{array}$ & Refs. \\
\hline Tumor size & Increase & +++ & $(12,17,24)$ \\
\hline Tumor shape & Increase & ++ & (6) \\
\hline $\begin{array}{l}\text { Cross-sectional area of } \\
\text { bone defect }\end{array}$ & Increase & +++ & (44) \\
\hline BMD & Increase & ++ & $(12,18,19)$ \\
\hline $\begin{array}{l}\text { Tumor location within } \\
\text { vertebrae }\end{array}$ & Increase & ++ & (6) \\
\hline $\begin{array}{l}\text { Upper, compared to lower, } \\
\text { thoracic vertebrae lesions }\end{array}$ & Increase & + & (24) \\
\hline $\begin{array}{l}\text { Costovertebral joint } \\
\text { destruction }\end{array}$ & Increase & + & $(10,17)$ \\
\hline Pedicle destruction & Increase & + & (39) \\
\hline Axial rigidity & Increase & + & $(20,22)$ \\
\hline Sagittal spinal deformity & Increase & ++ & $(25)$ \\
\hline Magnitude of spinal loading & Increase & ++ & $(3,42,43)$ \\
\hline Intact ribcage & Decrease & ++ & (3) \\
\hline Increased kyphotic angles & Decrease & ++ & (16) \\
\hline Transcortical lesions & Decrease & + & (16) \\
\hline
\end{tabular}

The number of $(+)$ denotes the cumulative predictive value a variable has on instability in the metastatic spine. Results based on variables from the studies reviewed here with high methodological quality and statistically significant predictive value.

results indicated that post-fracture stability was linearly correlated with both failure load $\left(\mathrm{r}^{2}=0.3-0.6\right)$ and axial rigidity $\left(r^{2}=0.3-0.6\right)$.

Whealan et al (22) examined whether the composite beam theory with image-derived structural rigidities could predict the failure load of whole vertebrae with a simulated osteolytic defect of intermediate size created in 1 of 3 locations. In addition, they tested the following hypotheses: i) That structural rigidities calculated from quantitative CT and dual-energy X-ray absorptiometric measurements correlate with measured failure load, ii) that correlations between calculated rigidity and failure load are independent of defect location and vertebral type, and iii) that composite beam theory can be used to predict the measured failure load of vertebrae with a simulated lytic defect of intermediate size. Although the relative defect size was nearly constant, the measured yield loads had a large dispersion, suggesting that defect size alone was a poor predictor of failure. However, image-derived measures of structural rigidity correlated moderately well with measured yield loads. Furthermore, by using the composite beam theory with quantitative CTderived rigidities, vertebral yield loads were predicted on a one-to-one basis (concordance, $\mathrm{r}=0.74$ ).

McGowan et al (23), examined metastatic lesions in thoracic vertebrae in vitro, in order to determine whether the reduction in the vertebral cross-sectional area could predict strength reduction. The normalized strength of thoracic vertebrae with trabecular defects was linearly related to the reduction in the cross-sectional area.
Retrospective studies. A study by Taneichi et al (24), determined the risk factors for vertebral body collapse caused by metastases, estimated the probability of collapse under various states of metastatic involvement, and established the criteria for impending vertebral body collapse. The risk factors for vertebral body collapse in the thoracic region (T1-T10) were tumor size and costovertebral joint destruction, whereas in the thoracolumbar and lumbar spine (T10-L5), tumor size and pedicle destruction were the main factors. The authors stated that the criteria of impending collapse in the thoracic spine was $50-60 \%$ involvement of the vertebral body with no destruction of other structures, or 25-30\% involvement with costovertebral joint destruction. In the thoracolumbar and lumbar spine, $35-40 \%$ involvement of the vertebral body, or 20-25\% involvement with pedicle destruction, indicated impending collapse.

Asdourian et al (25) performed an observational clinical study between October 1984 and January 1988 to determine the pathogenesis of spinal deformity and the cause of spinal canal compromise. Thirty-one magnetic resonance imaging (MRI) studies were performed on 27 patients with metastatic vertebral breast cancer. From these, a non-validated protocol was presented for treating patients with metastatic spinal involvement. The authors suggested that MRI could improve the understanding of the natural history of metastatic spinal deformities, helping in the recognition of instability and spinal canal compromise, before the onset of progressive deformity and neurologic sequelae.

Summary. A qualitative assessment of the studies demonstrated certain consistencies (Table III). The predictors of instability included increased tumor size $(12,17,24)$ and specifically a larger cross-sectional area of bone defect (23), increased force of spinal loading $(12,13,15)$, decreased bone density (12), posterior location of the tumor within the vertebrae $(14)$, destruction of the costovertebral joint $(17,24)$, pedicle destruction in the thoracolumbar spine (24), upper, compared to lower, thoracic vertebrae (16), increased axial rigidity $(20,22)$ and sagittal spinal deformity $(25)$. Preventative variables included the ribcage, which reduces burst fractures by $27 \%$ (15), increased kyphotic angles and transcortical lesions (16).

\section{Conclusions}

The Cochrane Review Group have accepted the systematic review as a very important advance in medical sciences (8). It is particularly useful in answering a specific question by objectively summarizing a body of literature containing methodological limitations. In this systematic review, we established what defines spinal instability or impending spinal instability in patients with metastatic disease of the thoracic and lumbar spine. Instability for this population is not well defined in the literature, and remains an important concept. Likewise, understanding factors that determine when a patient is at risk of developing spinal instability due to metastases is important for both the treating surgeon and the referring physician. Early identification of these lesions is necessary, as prompt referral and early surgical intervention can improve outcomes and survival for patients with spinal metastases. 
It is important to discuss instability in terms of fracture pattern as there are 2 general categories of pathological fracture, each with different underlying biomechanical mechanisms: i) Compression (wedge, or endplate) fracture, and ii) burst fracture (posterior wall involvement). Compression fractures have been modelled by using the tumor as a void. In this manner, metastatic compression fractures have been inadequately compared to osteoporotic fractures (26-36; Buckley JM, et al, 53rd Annual Meeting of the Orthopaedic Research Society, 2007). The tumor type and the effect on instability have not been adequately examined. It is well known that breast cancer metastases are osteolytic. However, sites with prostate cancer metastases often display distinctive osteoblastic reactions, characterized by high bone turnover rates with increased osteoid surface, osteoid volume, and mineralization rates (37). The tumor type could be even more critical in burst fractures, in that the fractures are induced by pressurization of the tumor. The poroelastic material behavior of the tumor tissue makes the origin of the primary tumor critical. In the metastatically-involved spine, the activities of daily living cause pressurization of the tumor tissue. Depending on tumor size, location (14), and type, pressurization can induce high circumferential tension in the cortical shell and, under sufficient load, can cause rupture.

This review contained no prospective clinical trials and all the human studies used were either retrospective or on cadaver spines. There have been no in vivo animal model studies on instability in metastatic spinal disease either. While several retrospective clinical studies were cited, all had limitations. For example, Taneichi et al (24), an often quoted study, examined the risk of tumor size and distribution on vertebral body collapse in the thoracic spine. The limitations of this study included the practical problem of measuring through extrapolation, the tumor extent at various time-points after the vertebrae had collapsed. Other assumptions were that new pain and/or a change in neurological findings were synonymous with collapse. It was also assumed that collapse was related to size and the extent of the tumor itself, not any other uncontrolled variables such as, extraspinal involvement or biomechanical forces (i.e. obesity or activity level at the time of the collapse). Additionally, it was assumed that tumor distribution at the time of collapse was predictive of the likelihood of collapse and not simply a reflection of the locoregional seeding of the vertebrae. Finally, not all the metastases examined were osteolytic, with osteoblastic prostate metastases constituting $15 \%$ of the sample size.

Other models $(13,38)$ were also developed as clinical burst fracture risk assessment tools were also reviewed. Biomechanical experiments and parametric finite element simulations (14-16,38-40) have shown that burst fracture risk generally increases with tumor size $\left(\mathrm{R}^{2}=0.51\right)(23)$. However, there is no clear threshold (13). Tumors are more likely to cause burst fractures if they are located in the posterior portion of the centrum $(14,16)$, the region most sensitive to changes in centrum pressurization, due to the 'bean' shape of the vertebra (39). Transcortical involvement decreases the risk of burst fracture, even when the tumor is located in the posterior region, as it allows the metastasis to depressurize without disrupting the surrounding cortical bone (16). Low bone density is associated with greater burst fracture risk, as is the narrowing of the spinal canal in the anteroposterior dimension $(16,41)$. The axial force component is the most critical loading parameter for burst fractures. The addition of bending and shear loads does not substantially decrease the threshold for fracture (15), which explains why kyphotic curvature and anterior endplate angulation have minimal effect on burst fracture risk (16).

The development and clinical implementation of finite element and detailed analysis (vertebral bulge and vertebral axial displacement equations) for clinical use is extremely resource-intensive and clinically impractical (13) especially for the referring physician. CT acquisition and analysis would have associated high costs based on the amount of operator time required to estimate tumor volumes since the image analysis software currently available is only semi-automated at best. These studies underscore the complexity of determining the predictors of fracture risk. In addition, BMD is not routinely assessed pre-operatively in metastatic patients, and can frequently be affected by previous irradiation.

When therapeutic intervention is required, the timing and method of treatment should be selected according to the variables predictive of instability or impending instability as determined by evidence-based medicine (EBM). Significant variables to be included are: i) Anatomic variables, ii) force characteristics, and iii) bone density and vertebral alignment. Anatomic variables were tumor size and location, involvement of the costovertebral junction, pedicle destruction and cortical defects. Force characteristics were load type and magnitude. Bone density variables were BMD and lytic lesions, while vertebral alignment factors were kyphosis, vertebral axial displacement and vertebral bulge. It should be remembered that these variables have been studied in isolation or independently and yet their interactive and/or cumulative effect is complex and probably unattainable. Presently, from a practical perspective, we can make the assumption that their effect is cumulative, but their magnitude of contribution binary (Table IV).

Further research in the form of a prospective clinical trial using the variables put forth in this review is being initiated to better delineate what defines instability and impending instability, although the feasibility and timing of this is uncertain. Therefore, in order to ensure an EBM process for the care of these patients, the integration of expert opinion with the information garnered from this review is the next logical step in optimizing care in this growing patient population.

\section{References}

1. American Cancer Society: Cancer Facts and Figures 2007. Atlanta, GA, American Cancer Society, 2007.

2. Toma CD, Dominkus M, Nedelcu T, Abdolvahab F, Assadian O, Krepler P and Kotz R: Metastatic bone disease: a 36-year single centre trend-analysis of patients admitted to a tertiary orthopaedic surgical department. J Surg Oncol 96: 404-410, 2007.

3. Sundaresan N, Digiacinto GV, Hughes JE, Cafferty M and Vallejo A: Treatment of neoplastic spinal cord compression: results of a prospective study. Neurosurgery 29: 645-650, 1991.

4. DeWald RL, Bridwell KH, Prodromas C and Rodts MF: Reconstructive spinal surgery as palliation for metastatic malignancies of the spine. Spine 10: 21-26, 1985.

5. Falicov A, Fisher CG, Sparkes J, Boyd MC, Wing PC and Dvorak MF: Impact of surgical intervention on quality of life in patients with spinal metastases. Spine 31: 2849-2856, 2006. 
6. Thomas KC, Nosyk B, Fisher CG, et al: Cost-effectiveness of surgery plus radiotherapy versus radiotherapy alone for metastatic epidural spinal cord compression. Int J Radiat Oncol Biol Phys 66: 1212-1218, 2006.

7. Cook DJ, Sackett DL and Spitzer WO: Methodologic guidelines for systematic reviews of randomized control trials in health care from the Potsdam Consultation on Meta-Analysis. J Clin Epidemiol 48: 167-171, 1995.

8. Van Tulder MW, Assendelft WJ, Koes BW and Bouter LM: Method guidelines for systematic reviews in the Cochrane Collaboration Back Review Group for Spinal Disorders. Spine 22: 2323-2330, 1997.

9. Guyatt G, Vist G, Falck-Ytter Y, Kunz R, Magrini N and Schunemann $\mathrm{H}$ : An emerging consensus on grading recommendations? Evid Based Med 11: 2-4, 2006.

10. Schunemann HJ, Jaeschke R, Cook DJ, et al: An official ATS statement: grading the quality of evidence and strength of recommendations in ATS guidelines and recommendations. Am J Respir Crit Care Med 174: 605-614, 2006.

11. Law M, Stewart D, Pollock N, et al: Critical Review Form Quantitative Studies. McMaster University, Hamilton, ON, 1998.

12. Whyne CM, Hu SS and Lotz JC: Burst fracture in the metastatically involved spine: development, validation, and parametric analysis of a three-dimensional poroelastic finiteelement model. Spine 28: 652-660, 2003.

13. Roth SE, Mousavi P, Finkelstein J, Chow E, Kreder H and Whyne CM: Metastatic burst fracture risk prediction using biomechanically based equations. Clin Orthop Relat Res 419: 83-90, 2004.

14. Tschirhart CE, Nagpurkar A and Whyne CM: Effects of tumor location, shape and surface serration on burst fracture risk in the metastatic spine. J Biomech 37: 653-660, 2004

15. Tschirhart CE, Finkelstein JA and Whyne CM: Metastatic burst fracture risk assessment based on complex loading of the thoracic spine. Ann Biomed Eng 34: 494-505, 2006.

16. Tschirhart CE, Finkelstein JA and Whyne CM: Biomechanics of vertebral level, geometry, and transcortical tumors in the metastatic spine. J Biomech 40: 46-54, 2007.

17. Ebihara H, Ito M, Abumi K, Taneichi H, Kotani Y, Minami A and Kaneda $\mathrm{K}$ : A biomechanical analysis of metastatic vertebra collapse of the thoracic spine: a sheep model study. Spine 29 994-999, 2004.

18. Hipp JA, Rosenberg AE and Hayes WC: Mechanical properties of trabecular bone within and adjacent to osseous metastases. J Bone Miner Res 7: 1165-1171, 1992.

19. Dimar JR, Voor MJ, Zhang YM and Glassman SD: A human cadaver model for determination of pathologic fracture threshold resulting from tumorous destruction of the vertebral body. Spine 23: 1209-1214, 1998.

20. Windhagen HJ, Hipp JA, Silva MJ, Lipson SJ and Hayes WC: Predicting failure of thoracic vertebrae with simulated and actua metastatic defects. Clin Orthop Relat Res 344: 313-319, 1997.

21. Windhagen H, Hipp JA and Hayes WC: Postfracture instability of vertebrae with simulated defects can be predicted from computed tomography data. Spine 25: 1775-1781, 2000.

22. Whealan KM, Kwak SD, Tedrow JR, Inoue K and Snyder BD Noninvasive imaging predicts failure load of the spine with simulated osteolytic defects. J Bone Joint Surg Am 82: 1240-1251, 2000 .

23. McGowan DP, Hipp JA, Takeuchi T, White AA III and Hayes WC: Strength reductions from trabecular destruction within thoracic vertebrae. J Spinal Disord 6: 130-136, 1993.

24. Taneichi H, Kaneda K, Takeda N, Abumi K and Satoh S: Risk factors and probability of vertebral body collapse in metastases of the thoracic and lumbar spine. Spine 22: 239-245, 1997.

25. Asdourian PL, Mardjetko S, Rauschning W, Jonsson H Jr, Hammerberg KW and Dewald RL: An evaluation of spinal deformity in metastatic breast cancer. J Spinal Disord 3: 119-134, 1990

26. Brinckmann P, Biggemann M and Hilweg D: Prediction of the compressive strength of human lumbar vertebrae. Spine 14: 606-610, 1989.
27. Buckley JM, Cheng L, Loo K, Slyfield $\mathrm{C}$ and $\mathrm{Xu} \mathrm{Z \text {: }}$ Quantitative computed tomography-based predictions of vertebral strength in anterior bending. Spine 32: 1019-1027, 2007.

28. Buckley JM, Loo K and Motherway J: Comparison of quantitative computed tomography-based measures in predicting vertebral compressive strength. Bone 40: 767-774, 2007.

29. Cheng XG, Nicholson PH, Boonen S, et al: Prediction of vertebral strength in vitro by spinal bone densitometry and calcaneal ultrasound. J Bone Miner Res 12: 1721-1728, 1997.

30. Crawford RP, Cann CE and Keaveny TM: Finite element models predict in vitro vertebral body compressive strength better than quantitative computed tomography. Bone 33: 744-750, 2003.

31. Ebbesen EN, Thomsen JS, Beck-Nielsen H, Nepper-Rasmussen HJ and Mosekilde L: Vertebral bone density evaluated by dual-energy X-ray absorptiometry and quantitative computed tomography in vitro. Bone 23: 283-290, 1998.

32. Edmondston SJ, Singer KP, Day RE, Price RI and Breidahl PD: Ex vivo estimation of thoracolumbar vertebral body compressive strength: the relative contributions of bone densitometry and vertebral morphometry. Osteoporos Int 7: 142-148, 1997

33. Eriksson SA, Isberg BO and Lindgren JU: Prediction of vertebral strength by dual photon absorptiometry and quantitative computed tomography. Calcif Tissue Int 44: 243-250, 1989.

34. Lochmuller EM, Burklein D, Kuhn V, Glaser C, Muller R, Gluer CC and Eckstein F: Mechanical strength of the thoracolumbar spine in the elderly: prediction from in situ dualenergy X-ray absorptiometry, quantitative computed tomography (QCT), upper and lower limb peripheral QCT, and quantitative ultrasound. Bone 31: 77-84, 2002.

35. Moro M, Hecker AT, Bouxsein ML and Myers ER: Failure load of thoracic vertebrae correlates with lumbar bone mineral density measured by DXA. Calcif Tissue Int 56: 206-209, 1995.

36. Singer K, Edmondston S, Day R, Breidahl P and Price R: Prediction of thoracic and lumbar vertebral body compressive strength: correlations with bone mineral density and vertebral region. Bone 17: 167-174, 1995.

37. Weber MH, Goltzman D, Kostenuik P, Rabbani S, Singh G, Duivenvoorden WC and Orr FW: Mechanisms of tumor metastasis to bone. Crit Rev Eukaryot Gene Expr 10: 281-302, 2000.

38. Whyne CM, Hu SS and Lotz JC: Biomechanically derived guideline equations for burst fracture risk prediction in the metastatically involved spine. J Spinal Disord Tech 16: 180-185, 2003.

39. Tschirhart CE, Roth SE and Whyne CM: Biomechanical assessment of stability in the metastatic spine following percutaneous vertebroplasty: effects of cement distribution patterns and volume. J Biomech 38: 1582-1590, 2005.

40. Whyne CM, Hu SS, Workman KL and Lotz JC: Biphasic material properties of lytic bone metastases. Ann Biomed Eng 28: 1154-1158, 2000

41. Whyne CM, Hu SS, Klisch S and Lotz JC: Effect of the pedicle and posterior arch on vertebral body strength predictions in finite element modeling. Spine 23: 899-907, 1998.

42. Vesterby A, Mosekilde L, Gundersen HJ, Melsen F, Mosekilde L, Holme K and Sorensen S: Biologically meaningful determinants of the in vitro strength of lumbar vertebrae. Bone 12: 219-224, 1991.

43. Pantel K and von Knebel D: Detection and clinical relevance of micrometastatic cancer cells. Curr Opin Oncol 12: 95-101, 2000.

44. McBroom RJ, Hayes WC, Edwards WT, Goldberg RP, White AA III: Prediction of vertebral body compressive fracture using quantitative computed tomography. J Bone Joint Surg Am 67: 1206-1214, 1985. 